\title{
Autopoiesis Sistem Sosial dalam Diskursus Penyelesaian Persoalan Bencana Asap di Indonesia
}

\author{
Arifudin ${ }^{1}$, Hermin Indah Wahyuni ${ }^{2}$, F Trisakti Haryadi ${ }^{3}$ \\ ${ }^{1}$ Jurusan Agribisnis, Fakultas Pertanian, Universitas Riau, Riau \\ ${ }^{1}$ Kampus Bina Widya Jalan H.R. Soebrantas Km. 12,5 Simpang Baru, Pekanbaru 28293, Indonesia \\ 1,2,3 Prodi Penyuluhan dan Komunikasi Pembangunan, Sekolah Pascasarjana, Universitas Gadjah Mada, Yogyakarta \\ ${ }^{1,2}$ Pusat Studi Sosial Asia Tenggara, Universitas Gadjah Mada, Yogyakarta \\ 1,2,3Jl. Teknika Utara, Pogung, Mlati, Sleman, Yogyakarta, 55281, Indonesia \\ Email: arif_udin@yahoo.com ${ }^{*}$; hermin_iw@ugm.ac.id ${ }^{2}$; trisakti-h@ugm.ac.id $^{3}$ \\ *corresponding author
}

\begin{abstract}
Peatland fires, as a cause of haze disasters, are very complex problems. In fact, when the smoke disaster in 2015 was still strong in the collective memory of people on the islands of Kalimantan and Sumatera, fires occurred again in 2018. This study aims to analyze how the parties communicate in finding permanent solutions to the resolution of the smoke disaster. This study uses a qualitative method by conducting discourse analysis from FGD and indepth interviews in Riau and West Kalimantan. The results showed that the social system of society is autopoiesis. Each party is open to hearing the other party's views, but will still refer to their respective interests. The results of this study suggest to the parties not to impose their respective interests in resolving peatland fires in Indonesia. Keywords: peatland fires, haze disaster, discourse, autopoietic.
\end{abstract}

\begin{abstract}
Abstrak
Kebakaran lahan gambut, sebagai penyebab bencana asap adalah persoalan yang sangat kompleks. Bahkan, ketika bencana asap di tahun 2015 masih kuat dalam ingatan kolektif masyarakat di Pulau Kalimantan dan Sumatera, kebakaran terjadi lagi di tahun 2018. Penelitian ini bertujuan menganalisis bagaimana para pihak berkomunikasi dalam menemukan solusi permanen penyelesaian bencana asap. Penelitian ini menggunakan metode kualitatif dengan cara melakukan analisis diskursus dari FGD dan wawancara mendalam di Riau dan Kalimantan Barat. Hasil penelitian menunjukkan bahwa sistem sosial masyarakat bersifat autopoiesis. Masing-masing pihak terbuka untuk mendengar pandangan pihak lain, namun akan tetap mengacu kepada kepentingannya masing-masing. Hasil penelitian ini menyarakan kepada para pihak untuk tidak memaksakan ego kepentingannya masing-masing dalam penyelesaian kebakaran lahan gambut di Indonesia.
\end{abstract}

Kata Kunci: kebakaran lahan gambut, bencana asap, diskursus, autopoiesis.

\section{Pendahuluan}

Kebakaran gambut sebagai penyebab terjadinya bencana asap, telah disadari oleh Pemerintah Indonesia sebagai kesalahan dalam pengelolaan lahan gambut. Ekosistem lahan gambut alami yang basah terlanjur dikeringkan untuk kepentingan budidaya pertanian, khususnya perkebunan kelapa sawit dan Hutan Tanaman Industri (HTI), selain untuk tanaman pangan, dan pemukiman (Dohong, Aziz, \& Dargusch, 2017; Tata, Narendra, \& Ginoga, 2017). Pada awal tahun 2016 pemerintah telah merespon penyelesaian terkait persoalan ini dengan membentuk Badan Restorasi Gambut (BRG). BRG memiliki misi 3R, yakni rewetting, revegetation, dan revitalization of livelihood. Tujuannya untuk melindungi gambut yang masih bisa diselamatkan, memperbaiki gambut yang terdegradasi, dan menyejahterakan masyarakat yang hidup di lahan gambut (Safitri, 2016). Masih terdapat tantangan-tantangan, baik persepsi, penerimaan, kelembagaan dalam melakukan kegiatan-kegiatan restorasi gambut guna mencegah terjadinya kebakaran lahan gambut yang lebih luas (Carmenta, Zabala, Daeli, \& Phelps, 2017; Kittie, Schouten, \& Hein, 2018).

Pada tahun 2016-2017, kejadian kebakaran lahan dan hutan menurun drastis. Tahun 2018, bencana asap ini datang kembali. Hal ini menyebabkan diliburkannya sekolah dan 


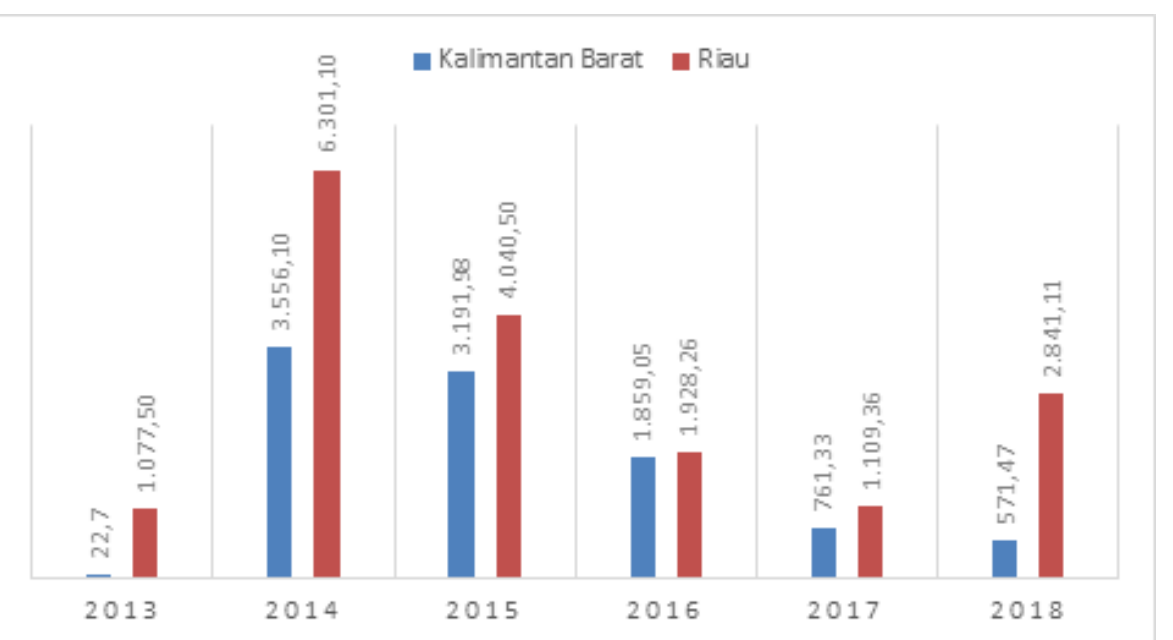

Gambar 1. Luas Kebakaran Hutan dan Lahan (Ha) di Provinsi Kalimantan barat dan Riau (2013-2018) Sumber: http://sipongi.menlhk.go.id, (diakses 12 September 2018)

terganggunya aktifitas sosial ekonomi masyarakat di Indonesia, seperti yang terjadi di Kabupaten Sintang, Kabupaten Melawi, dan Kabupaten Sambas di Propinsi Kalimantan Barat. Ratusan hektar lahan gambut juga terbakar di Kabupaten Kepulauan Meranti, Riau di tahun yang sama. Hal ini menunjukkan kejadian kebakaran lahan gambut masih berpotensi terjadi dimasa yang akan datang. Oleh sebab itu diperlukan kesepahaman dalam sistem sosial masyarakat untuk mencari solusi permanen dalam mengatasi kebakaran lahan gambut agar tidak terulang lagi. Luhmann (1995 [1983]), berargumen bahwa dalam sebuah sistem sosial akan berlaku sebuah sistem yang bersifat autopoiesis. Konsep ini awalnya diperkenalkan oleh Varela dan Maturana (1980), dalam ilmu biologi untuk menjelaskan bagaimana sistem bekerja di dalam tubuh makhluk hidup. Luhmann mengadopsi dan mengembangkannya dalam konteks sosial untuk menjelaskan bagaimana sistem sosial bekerja. Autopoiesis adalah istilah yang digunakan untuk menjelaskan bahwa sistem selalu bersifat terbuka dan sekaligus tertutup. Sistem membentuk struktur sendiri sebagai reaksi terhadap gangguan lingkungan untuk melanjutkan proses autopoiesis pada sub-sistemnya (Leydesdorff, 2014). Artinya, sistem bersifat terbuka terhadap gangguan yang berasal dari lingkungan (sistem lainnya), dan sekaligus bersifat tertutup, ketika merefensi kepentingannya, dengan kodenya masing-masing. Seperti sistem ekonomi dengan kodenya "untung" atau "tidak untung" dan sistem politik dengan kodenya "berkuasa" atau "tidak berkuasa". Naruse \& Iba (2008) menggambarkan konsep autopoiesis tersebut dalam sebuah abstraksi agar lebih mudah dipahami, sebagaimana pada Gambar 2 .

Operasi autopoeisis di dalam sistem sosial adalah komunikasi. Komunikasi terdiri dari tiga elemen, yakni informasi (information), pengungkapan (utterance), dan pemahaman (understanding) (Luhmann, 1982). Proses ini akan menciptakan makna, dimana setiap proses merupakan seleksi dari setiap tahapan.

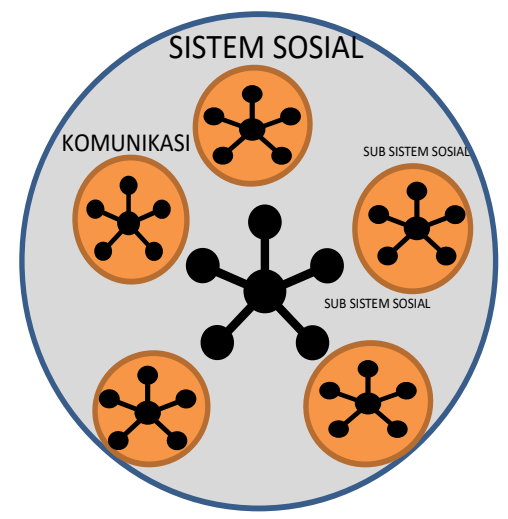

Gambar 2. Abstraksi sistem sosial yang bersifat autopoiesis

Sumber: Modifikasi dari Naruse \& Iba (2008) 
Dari sekian banyak informasi yang disediakan, tidak semuanya akan diungkapkan, dari sekian banyak yang diungkapkan, tidak semua juga dapat dipahami. Proses ini tidak akan pernah berhenti pada satu titik, ia akan berproses selalu dan menciptakan proses autopoiesis di dalam sistem sosial (Ritzer, 2012).

Pentingnya kedudukan komunikasi membuat Luhmann (1995 [1983]), meyakini bahwa society of society is communication (masyarakat dari masyarakat adalah komunikasi). Oleh sebab itu tulisan ini mengajukan sebuah pertanyaan penting, "apa yang terjadi dalam sistem sosial masyarakat yang selalu berkomunikasi, namun kebakaran lahan gambut ini belum menemukan solusi permanennya?"

Terdapat beberapa penelitian, terutama yang terbaru dari perspektif komunikasi terhadap kejadian bencana asap di Indonesia, seperti penelitian yang dilakukan oleh Carmenta et al. (2017) tentang persepsi masyarakat di berbagai level terhadap bencana asap di Indonesia dan penelitian tentang diskursus bencana asap di televisi tahun 2015 yang dilakukan oleh Zadok (2017). Penelitian diskursus bencana asap yang disebabkan oleh maraknya Industri yang menghasilkan polusi udara, pernah dilakukan oleh Huang (2017) di Republik Rakyat Cina. Huan meneliti bagaimana kontruksi realitas masyarakat terhadap bencana asap yang disajikan oleh berita harian Cina.

Penelitian ini berbeda dengan penelitianpenelitian tersebut, dimana sejauh pengamatan peneliti, belum pernah ada riset sebelumnya yang mengkaji dikursus di masyarakat tentang persoalan bencana asap dengan menggunakan perspektif sistem sosial yang digagas oleh Niklas Luhmann. Oleh sebab itu penelitian ini bertujuan untuk menganalisis bagaimana para pihak berkomunikasi secara langsung dalam menemukan solusi permanen penyelesaian bencana asap.

\section{Metode Penelitian}

Penelitian inimenggunakan metodekualitatif dengan cara melakukan analisis diskursus dari FGD dan wawancara mendalam. Data yang digunakan dalam penelitian ini adalah diskursus yang dikemukakan oleh masing-masing pihak secara langsung dalam mencari solusi bencana asap di Propinsi Kalimantan Barat dan Propinsi Riau. Adapun teknik pengumpulan data dilakukan dengan menggunakan Focus Group Discussion (FGD) dan wawancara secara mendalam kepada

Tabel 1. Para pihak dan informan

\begin{tabular}{|c|c|c|c|c|c|}
\hline \multirow[t]{2}{*}{ No } & \multirow[t]{2}{*}{ Nama Lembaga } & \multicolumn{2}{|c|}{ Riau } & \multicolumn{2}{|c|}{ Kalimantan Barat } \\
\hline & & Wawancara & FGD & Wawancara & FGD \\
\hline \multirow[t]{9}{*}{ A } & Pemerintah & & & & \\
\hline & $\begin{array}{l}\text { 1. Dinas Lingkungan Hidup dan } \\
\text { Kehutanan(DLHK) }\end{array}$ & V & V & V & V \\
\hline & $\begin{array}{l}\text { 2. Badan Penanggulangan Bencana } \\
\text { Daerah (BPBD) }\end{array}$ & V & V & V & V \\
\hline & 3. Manggala Agni (MA) & & $\mathrm{V}$ & & V \\
\hline & 4. Dinas Pendidikan dan Kebudayaan & $\mathrm{V}$ & $\mathrm{V}$ & $\mathrm{V}$ & $\mathrm{V}$ \\
\hline & 5. Dinas Pertanian dan Perkebunan & & $\mathrm{V}$ & V & V \\
\hline & 6. Kanwil Agama & & & & \\
\hline & 7. Kepolisian (Polda) & & & & \\
\hline & 8. Perguruan Tinggi & & & & \\
\hline
\end{tabular}




\begin{tabular}{|c|c|c|c|c|c|}
\hline \multirow[t]{2}{*}{ No } & \multirow[t]{2}{*}{ Nama Lembaga } & \multicolumn{2}{|c|}{ Riau } & \multicolumn{2}{|c|}{ Kalimantan Barat } \\
\hline & & Wawancara & FGD & Wawancara & FGD \\
\hline \multirow[t]{7}{*}{$\mathrm{B}$} & Koperasi & & & & \\
\hline & 1. PT. VM & V & & & \\
\hline & 2. PT. AA & V & & V & \\
\hline & 3. PT. RC & & & $\mathrm{V}$ & V \\
\hline & 4. PT. Pw & & & V & V \\
\hline & 5. PT JP & & $\mathrm{V}$ & & \\
\hline & 6. PT. SS & & & V & $\mathrm{V}$ \\
\hline \multirow[t]{8}{*}{$\mathrm{C}$} & $\begin{array}{l}\text { Masyarakat/Lembaga Swadaya } \\
\text { Masyarakat }\end{array}$ & & & & \\
\hline & 1. Wahana Lingkungan Hidup & V & & V & \\
\hline & 2. Seruni & $\mathrm{V}$ & & & V \\
\hline & 3. Scale-Up & V & & & \\
\hline & 4. Jaringan Masyarakat Gambut & $\mathrm{V}$ & & & \\
\hline & 5. Jikalahari & V & $\mathrm{V}$ & & \\
\hline & 6. Yayasan Pancur Kasih & & $\mathrm{V}$ & & \\
\hline & 7. Masyarakat Peduli Api & $\mathrm{V}$ & $\mathrm{V}$ & $\mathrm{V}$ & \\
\hline
\end{tabular}

Sumber: Dokumen Peneliti, (2018)

para pihak sebagaimana disajikan pada tabel 1 . Dalam pelaksanaan FGD di Kalimantan Barat dan Propinsi Riau, peneliti menghadirkan para pihak yang mewakili unsur pemerintah, korporasi, dan lembaga swadaya masyarakat dan masyarakat dari lokasi lahan gambut yang sering terbakar.

Analisis data dilakukan dengan cara analisis kualitatif, yakni dengan menganalisis diskursus yang mengemuka dari masing-masing pihak dalam memandang persoalan bencana asap, terutama cara pandang masing-masing pihak dalam menentukan solusi permanen penyelesaiannya. Data dikategorisasi, direduksi, dibuat simpulan, dan dibahas dengan menggunakan perspektif Luhmann tentang sistem sosial.

\section{Hasil Penelitian dan Pembahasan}

Dari sekian banyak diskursus tentang penyelesaian bencana asap di Kalimantan Barat dan Riau dapat direduksi tema-tema yang paling menonjol dalam penyelesaian bencana asap. Tema tersebut berkaitan dengan isu pentingnya ketersediaan air dan akses ke lokasi kejadian kebakaran, masyarakat peduli api, tanggung jawab korporasi dan pembinaan masyarakat, pendekatan agama, dan yang terpenting adalah diskursus tentang upaya restorasi lahan gambut. Pentingnya ketersediaan air dan akses ke lokasi kejadian kebakaran lahan

Air merupakan kata kunci yang sangat penting dalam penyelesaian bencana asap. Ketika terjadi kebakaran, air sangat diperlukan, untuk memadamkan api secara langsung oleh anggota Manggala Agni, water boombing dengan menggunakan helikopter, modifikasi cuaca dengan cara menebarkan garam pada awan menggunakan pesawat agar menghasilkan hujan, dan juga dalam upaya restorasi lahan gambut. Dalam diskusi, hampir semua pihak, baik pemerintah, korporasi, LSM, maupun 
masyarakat sepakat dengan pentingnya air. Jika tidak ada air, maka kebakaran lahan gambut tidak akan bisa diselesaikan: "no water no solution", seperti yang diungkapkan oleh kepala Daop Manggala Agni Pontianak, sebagai berikut. "Jadi, no water itu hubungannya dengan saluran irigasi, dan lain-lain, atau apalah bahasanya. Pokoknya saluran air lah. Karena ini ada hubungannya dengan peta kerawanan yang kita bikin. Jadi, no water ini termasuk ketika ada kebakaran pun, kami bersama para pihak pernah hanya jadi penonton. Karena memang tidak bisa ada air, tanpa bermaksud membela water bombing yang dilakukan BPBD. Ketika sudah ndak ada air di dekat situ, ndak bisa mesin merapat, tentulah helikopter menjadi salah satu Nawacita, Indonesia berbuat di mata asing" (SD, FGD,13 September, 2018).

Kendala ini disampaikan juga oleh BPBD Riau, ketika mencoba memadamkan kebakaran lahan di beberapa tempat yang aksesnya tidak dapat dijangkau. "Untuk kami di lapangan, kendala yang dialami selama ini khususnya kalau dalam penanganan karhutla ini, kadang-kadang jarak dan area yang sangat luas. Kadangkadang sampai dinyatakan bentuk tempattempat, dia sampai ada Robin untuk nyedot air, semprot langsung ke area. Bahkan karena istilahnya selang atau alat itu yang sangat terbatas, tidak bisa sampai ke sasaran. Itulah yang datang bombingbombing dari udara untuk mencegah itu. jadi ada istilahnya satgas darat, satgas udara" (HS, FGD, 27 September 2018) Pada satu kasus, untuk mengambil air, helikopter yang sedang melakukan water boombing, terpaksa harus kembali ke pangkalan udara yang jaraknya bisa menempuh waktu dua jam. Hal ini menunjukkan bahwa isu air adalah isu paling penting pada kasus bencana asap, baik dalam memadamkan api, membersihkan udara, dan terutama dalam usaha merestorasi lahan gambut yang terdegradasi. Masyarakat Peduli Api (MPA) dan patroli bersama

Keberadan MPA diakui oleh semua pihak sebagai kelompok yang sangat strategis untuk mencegah kebakaran lahan lebih dini. Berbagai macam nama kelembagaan masyarakat peduli api telah dibuat oleh berbagai pihak dengan berbagai versinya. Korporasi membentuk MPA untuk menjaga kepentingan konsesinya. Penamaan kelompok MPA pun berbedabeda. MPA itu sendiri, KTPA (Kelompok Tani Peduli Api) oleh Dinas Perkebunan, dan MSA (Masyarakat Sadar Api) oleh salah satu grup korporasi. Keluhan yang sering muncul dari MPA adalah persoalan honor (insentif) untuk anggota dan juga peralatan yang tidak memadai.

"Kami juga melakukan pembinaan. Pembinaan itu adalah pembinaan MPA. Jadi pembinaan MPA ini maksudnya MPA yang sudah terbentuk, kami melakukan pembinaan. Memang kendala-kendalanya ketika melakukan pertemuan pembinaan itu semuanya rata-rata masalah honor. Itu memang klausul yang dari awalawal dibentuk MPA ini bicaranya honor terus," (EV, FGD, 27 September 2018)

Secara teori, kelompok tani sebenarnya adalah kelompok yang strategis sebagai MPA. sebab MPA selain sebagai kelompok yang paling cepat meresponnya ketika terjadi kebakaran, namun juga mampu berfungsi sebagai media pembelajaran, peningkatan kapasitas masyarakat, dan juga peningkatan ekonomi masyarakat dengan kegiatan ekonomi yang produktif (Arifudin, Nasrul, \& Maswadi, 2013). Selain melakukan patroli secara swadaya di Desa, MPA juga berpatroli bersama-sama dengan petugas Babinsa (TNI atau Bintara Pembina Desa), Bhabinkamtibmas (Polisi atau Bhayangkara Pembina Keamanan dan Ketertiban Masyarakat), dan Manggala Agni. Program yang diinisiasi oleh KLHK ini terbukti efektif menekan jumlah kejadian kebakaran lahan selama tahun 2016-2017. Namun demikian, selalu memunculkan pertanyaan "sampai kapan pemerintah harus mengalokasikan anggaran khusus untuk kegiatan patroli bersama, agar tidak terjadi kebakaran lahan lagi?"

Tanggung jawab korporasi dan pembinaan masyarakat 
Korporasi perkebunan kelapa sawit dan HTI bereaksi dengan melaksanakan programprogram untuk mengatasi kebakaran lahan di sekitar konsesi mereka. Data World Bank (2016) menunjukkan kebakaran terbesar adalah APL (Area Penggunaan Lain), perkebunan kelapa sawit, dan HTI. Biasanya pembakaran APL guna persiapan lahan untuk ditanami kelapa sawit. Ketika fakta ini disampaikan, pihak korporasi merasa keberatan, sebab konsesi korporasi tidak seluruhnya meliputi perkebunan yang telah ditanam. Bisa jadi lahan yang terbakar tersebut adalah wilayah HCV (High Conservation Value) yang diokupasi oleh masyarakat.

Sebagai bentuk tanggung jawab, baik secara terpaksa maupun sukarela, korporasi melakukan kegiatan pembinaan kepada masyarakat melalui program CSR (Corporate Social Responsibility), seperti program Desa Bebas Api. Bahkan beberapa korporasi memberikan reward 100 juta rupiah, jika desa tersebut mampu zero kejadian kebakaran lahan gambut. Hal ini dilakukan oleh korporasi perkebunan kelapa sawit dan HTI untuk mencegah kebakaran yang menurut mereka selalu berawal dari lahan di masyarakat yang merembet ke lahan konsesi. Belum semua korporasi melakukan pembinaan masyarakat melalui kegiatan CSR. Masih ada korporasi yang menganggap kegiatan pembinaan masyarakat bukan tanggung jawab mereka.

"Memang Sinarmas, selain melakukan, membina masyarakat siaga api tadi, infrastruktur juga kita lengkapi, termasuk sarpras, sarana prasarana, kalau tanpa itu, istilahnya mungkin teman-teman Manggala Agni bilang "tanpa senjata"-lah, seperti itu, ya Mas ya? “(Bn, FGD, 13 September 2018)

Terhadap kegiatan CSR yang dilakukan oleh korporasi ini, terdapat berbagai pandangan yang beragam. Tidak semuanya juga melihatnya secara positif. Bahkan pihak pemerintah yang terbantu juga tidak terlalu optimis dengan CSR tersebut. Terutama LSM, yang meminta korporasi tidak melepaskan tanggungjawab pelanggaran hukumnya dengan melakukan kegiatan CSR.
"Kami pas pembukaan itu kami ngikut. Ngikut-ngikut apa itu Pak Gubernur, pak apa itu, dia memberikan dana dari CSR itu dia itu seratusan, seratusan juta lebih. Tiap program itu, apa itu, ada berapa desa itu lingkungan gambut. Ada 8 desa kalau ndak keliru itu dikasih semua! Selain itu juga "dia diberi perhatian, masyarakat kirakira, kan gitu. Masyarakat ini nanam apa sih yang cocok nih, gini lo... Gimana CSR nya? kalau ndak kita undang, kita pernah undang juga disini. Dia apasih yang akan diberikan ketika dia bekerja disitu, ini mencari untung disini. Ada juga korporasi yang memberikan alat, apa tu, alat pemadam tu." (Sy, wawancara, 10 November 2017). Selain itu terdapat peraturan-peraturan yang telah disusun oleh pemerintah melalui Peraturan Menteri Lingkungan Hidup dan Kehutanan dan Permen Pertanian tentang prosedur pembukaan lahan dan kesiap-siagaan dalam menghadapi kebakaran lahan sudah dipersiapkan dan disosialisasikan kepada korporasi. Seperti yang diungkapkan oleh perwakilan Dinas Pertaniandan Dinas Perkebunan Provinsi Kalimantan Barat. "Kalau korporasi itu mau mendapatkan izin, itu ada beberapa persyaratannya. Itu termasuk ada sumber daya, sarana prasarana, dan pengendalian kebakaran. Jadi mungkin seperti kata bapak Pratama tadi, itu memang menurut Permentan No. 5 tahun 2018 itu di situ tercantum sarana dan prasarana untuk pengendalian kebakaran itu sekian sekian gitu Pak. Misalnya satu regu harus ininya sekian, itu ada di Permentan. Jadi semua korporasi untuk izin itu harus punya sarana dan prasarana kebakaran. Dan kami dari Dinas Perkebunan itu sudah mensosialisasikan itu dalam Undangundang No. 39 tahun 2018. Setiap korporasi yang membuka lahan itu tidak boleh dibakar. Jadi, seperti kata dari Pertanian tadi, pembukaan lahan tanpa bakar. Mungkin itu Pak untuk Undang-undang No. 39-nya. Dan di undang-undang itu, itu juga ada sanksinya Pak, untuk korporasi perkebunan yang membuka lahan dengan membakar. Dengan sanksinya sepuluh milyar Pak. Jadi mungkin kalau korporasi perkebunan itu nggak mungkin membakar, karena ya kerugiannya besar, terus sanksinya juga besar" (IG, 13 September 2018). 
Sejak peristiwa bencana asap 2014 dan 2015, korporasi-korporasi yang beroperasi di lahan gambut berusaha memenuhi peralatan pemadam kebakaran, sesuai dengan peraturan yang berlaku. Hal ini merupakan paksaan pemerintah kepada pelaku dunia usaha, untuk betanggung jawab dan memiliki kesiapsiagaan menghadapi kebakaran lahan di wilayah konsesi yang mereka kuasai. Begitu juga dengan pembinaan masyarakat.

Prinsip dasar kegiatan pembinaan ini adalah bahwa perubahan individu pada masyarakat dapat ditempuh dengan kegiatan pembinaan oleh pemerintah, korporasi, maupun pendampingan yang dilakukan oleh LSM. Selain itu perlu juga insentif kepada petani agar tidak melakukan pembakaran lahan. Insentif tersebut dapat diberikan melalui CSR korporasi dan program pemerintah melalui dinas pertanian, perkebunan, dan terutama lembaga penyuluhan pertanian. Penegakan hukum: larangan membakar lahan

Membakar lahan adalah perbuatan melawan hukum, baik yang dilakukan oleh korporasi maupun perorangan. Pada tahun 2018, menurut laporan kepolisian yang disampaikan dalam diskusi, terdapat 35 tersangka pembakar lahan di wilayah hukum Kalimantan Barat, dan 32 tersangka di Riau. Artinya, masih cukup tinggi pelaku pembakar lahan.

Diskursus yang juga selalu mengemuka dan tidak menemukan jalan keluarnya adalah diskursus penerapan Undang-undang No 32 tahun 2009 tentang Lingkungan Hidup, khususnya pada pasal larangan membuka lahan dengan cara membakar. Penjelasan pasal 69 selalu memuculkan perdebatan tentang masihnya diperbolehkan membakar lahan, jika terdapat kearifan lokal. Disatu sisi, hal ini memiliki semangat membela masyarakat tradisional yang memiliki kebiasaan membakar secara turun temurun. Ironisnya, terdapat pihak-pihak yang berlindung di balik pasal ini untuk melakukan pembakaran. Akademisi dari Universitas Tanjung Pura meminta agar tambahan penjelasan tersebut dihapuskan, supaya tidak menimbulkan kesalahan persepsi dan dalih untuk tetap melakukan pembakaran lahan.

Kenyataannya, pasca kejadian bencana asap 2015, masyarakat tidak lagi berani membuka lahan dengan cara membakar secara terang-terangan. Hal ini memunculkan reaksi negatif dari sebagian masyarakat, yang disuarakan oleh LSM-LSM di Kalimantan Barat dan Riau. Mereka berpendapat bahwa larangan ini menyebabkan mereka tidak bisa lagi melakukan kegiatan berladang. Sebagai contoh kasus petani jagung di Kab. Pelalawan, Riau, sebagaimana yang dikemukakan oleh perwakilan JMGR. "Secara ekonomi masyarakat itu menurun. Ini bisa kita lakukan studi itu di kabupaten Pelalawan, khususnya di kecamatan Kuala Kampar dan kecamatan Teluk Meranti. Jadi, ada dua desa yang memang dari dulu itu melakukan pertanian jagung dan mereka dari dulunya itu hanya melakukan dengan cara membakar. Itu ada dua desa yang memang intens melakukan pertanian, sekitar 700KK itu memang bergantung pada pertanian jagung. Jadi di 2014 itu mereka memang tidak bisa melakukan kegiatan pertanian itu sama sekali, karena memang tidak boleh membakar, kemudian tidak ada solusi yang jelas, atau yang pasti bagaimana untuk mereka tetap melanjutkan kegiatan mereka itu" (Syaf, FGD, 27 September 2018) Muncul juga upaya pemerintah agar tidak lagi membakar lahan, dengan memberikan alternatif solusi membuka lahan, seperti yang disampaikan olehperwakilanDinasPertanianKalimantanBarat. "Kami melakukan pengelolaan lahan tanpa bakar itu sudah lama sudah lama kita lakukan sosialisasi, bisa dilihat dengan perkembangan perilaku petani kita, walaupun tidak signifikan. Di daerah hulu dan lain-lain sudah banyak berubah, tidak mau lagi membakar, karena mereka juga sudah tahu, pertama "Bu kalau membakar lahan kena tangkap $\mathrm{Bu}$, masuk penjara". Mereka sudah mulai memahami, karena seperti tadi Pak S bilang, ada yang kalau ada polisi dia tidak bakar, tapi malam-malam bakar. Pintar Pak, lihat satelit $\mathrm{Bu}$ katanya. Jadi ada yang lihat satelit---Kalau ndak ada Bu, kita bakar, karena kami 
orang di lapangan, dan kita menyaksikan keadaan petani kita. Memang tidak bisa kita frontal melawan mereka untuk langsung tidak membakar, kalau kita tidak memberi solusi alternatif terhadap pola budidaya yang sering mereka lakukan. Kami dengan PPL kami sudah berkali-kali kita coba untuk lebih memperbesar, merubah perilaku budidaya dengan pengelolaan lahan tanpa bakar" (Id, FGD, 13 September 2018).

Sayangnya, solusi alternatif yang diberikan tersebut juga belum memuaskan masyarakat. Aktifis LSM Kalimantan Barat sangat tidak setuju jika petani dilarang membakar, selama belum ada solusinya. Menurut aktifis LSM menyatakan bahwa jika masyarakat membakar, biasanya masyarakat tidak pernah meluas, dan dalam waktu tiga jam api juga sudah padam.

\section{Diskursus pendekatan agama}

Pendekatan agama dalam menyelesaikan persoalan bencana asap juga menjadi diskursus yang menarik. Dalam sebuah diskusi dinyatakan bahwa segala upaya yang dilakukan oleh pihak kepolisian untuk melakukan pencegahan, pemadaman, dan penindakan kepada pembakar lahan, dinilai tidak berhasil menyudahi bencana asap. Akhirnya, pihak kepolisian meminta kepada Majelis Ulama Indonesia (MUI) daerah untuk mengeluarkan fatwa tentang "haram melakukan pembakaran hutan dan lahan".

Hal menarik lainnya adalah satgas doa yang dipersiapkan oleh BPBD Kalimantan Barat. Kanwil Kemenag Kalimantan Barat juga menerbitkan naskah Khutbah Idul Adha tentang larangan membakar lahan. Sholat istisqa juga selalu diselenggarakan guna mengajak masyarakat untuk meminta hujan kepada Tuhan. Namun demikian, pertanyaan pesimis muncul "kenapa bencana ini bisa terulang setiap tahunnya, padahal terus dihimbau melalui pendekatan agama?".

"Baik, dari Kementerian Agama, kami itu sudah berusaha dan berupaya memberikan himbauan, penyuluhan agama, dakwah, melalui penyuluh-penyuluh dan petugaspetugas agama-agama kita di kabupaten/ kota se-Kalimantan Barat..... Kemudian pada saat Idul Adha kemarin itu, kita juga ada membuat suatu konsep khotbah Idul Adha kepada rekan-rekan kita yang sebagai petugas khatib-nya untuk menyampaikan juga larangan atau di sini ada sebuah konsep khotbah ini larangan terhadap pembakaran hutan dan lahan. Kemudian selanjutnya, dari Majelis Ulama Indonesia khususnya di Kalimantan Barat, itu juga sudah berkali-kali mengeluarkan fatwa MUI-nya, itu yang fatwa MUI itu dari 2016 malahan Pak, tahun 2016 nomor 30 tentang Hukum Pembakaran Hutan dan Lahan serta Pengendaliannya. Itulah Pak, langkah-langkah dan upaya yang kami lakukan. Tetapi ada pertanyaan, barangkali ada pertanyaan. Setiap tahun kita semuanya sudah kita lakukan dengan cara sosialisasi penyuluhan agama, dengan seminar dan lainnya lagi. Sudah kita lakukan tiap tahun. Pertanyaannya, kenapa masih ada lagi (asapnya)?" (RT, FGD, 13 September 2018) Disini menunjukkan bahwa, pihak Kanwil Agama tidak disuplai dengan baik tentang penjelasan ilmiah penyebab kebarakan lahan gambut. Padahalmerekayangmenyiapkannaskah khutbah, memfasilitasi sholat istisqa beserta pelaksana khutbahnya. MUI juga mengeluarkan fatwa. Ironisya, menurut akademisi dari Universitas Tanjungpura bahwa selama kejadian asap di bulan Agustus 2018, jarang khatib Jum'at yang menyinggung persoalan kerusakan lingkungan, padahal ketika itu asap yang sedang tebal-tebalnya menyelimuti Kalimantan Barat.

\section{Pentingnya Restorasi Gambut}

Restorasi gambut merupakan agenda penting Pemerintah Indonesia sejak tahun 2016 sampai dengan 2020, sebagai upaya penyelesaian bencana asap di Indonesia, diwujudkan dengan terbentuknya Badan Restorasi Gambut (BRG), dengan misi 3 R, yakni Rewetting, Revegetation, dan Revilalisasi livelihood. Kegiatan restorasi gambut diharapkan sebagai kegiatan strategis penyelesaian bencana asap di Indonesia.

Dalam kenyataannya, diskursus tentang upaya yang positif ini tidak terlalu menonjol, justru terjadi sikap yang pesimis dengan jalannya kegiatan restorasi gambut di daerah. Hal ini dikemukakan oleh Manggala Agni 
Kalbar, LSM Jikalahari, Yayasan Pancur Kasih. Sikap ini muncul sebab kegiatan kelembagaan restorasi gambut di daerah, yang belum mampu merangkul para pihak di daerah untuk menyukseskan kegiatan restorasi gambut. Pihak pemerintah daerah, mengakui bahwa terdapat berbagai kendala teknis yang menghambat pelaksanaan restorasi gambut, sebagai contoh lambannya turunnya dana dari pemerintah pusat.

"Sebelumnya maaf, TRGD selalu di luar sana kita dengar disalahkan kok targetnya nggak jalan gitu. Apa ini TRGD Riau ini kalah dari TRGD di Kalimantan sama Sumatra Selatan. Sebenarnya bukan kita tidak jalan, tapi anggaran untuk TRGD itu baru keluar dari kementerian itu bulan Juni. Bulan lima sebenarnya sudah keluar, tapi ada revisi dari kementerian dan kita baru bisa pakai itu bulan Juli, kalau nggak salah.”. (Rd, FGD, 27 September 2018) Disamping itu, sebagian korporasi dan asosiasi petani kelapa sawit keberatan dengan kebijakan restorasi lahan gambut terkait dengan PP 57 tahun 2016, khususnya aturan untuk menjaga muka air (water table) air gambut setinggi 0,4 meter, yang dinilai tidak pro dengan pembangunan industri kelapa sawit di Indonesia. Begitu juga aturan turunannya, yakni Permen KLHK No 17 tahun 2017 yang mengharuskan mereka harus keluar, menghentikan kegiatan budidaya yang masuk zona kawasan lindung gambut, serta bertanggungjawab memulihkan lahan gambut yang terlanjur diekploitasi.

Diskursus yang muncul di masyarakat, terutama yang dikemukakan secara langsung, merupakan kontruksi realitas yang ada dimasyarakat yang tidak bias media, dan bisa dikonfirmasikan keabsahannya. Perbedaan cara pandangmasing-masingpihakdalampenyelesaian kebakaran lahan gambut ini telah diprediksi oleh Luhmann (1989) yang menyatakan bahwa sistem sosial masyarakat itu bersifat autopoiesis dalam mengkomunikasikan persoalan ekologi.

Pada diskursus tentang pentingnya air untuk melakukan pemadaman kebakaran lahan gambut, yang disampaikan oleh Manggala
Agni (MA), selaku pihak yang langsung turun tangan memadamkan api. MA pesimis dengan kinerja TRGD di Kalimantan Barat yang tidak melibatkan mereka dalam merestorasi lahan gambut. Begitu juga dengan pihak kepolisian, yang telah melakukan kegiatan pemadaman api dengan berbagai upaya seperti penegakan hukum hingga meminta fatwa MUI. Kegiatan restorasi gambut bukan tema prioritas. Di Propinsi Riau, dimana para pihak memiliki persepsi yang positif terhadap pentingnya restorasi gambut. Akan tetapi dukungan nyata dalam kegiatan gambut untuk mengembalikan gambut untuk dapat mempertahankan kelembabannya, dinilai masih belum optimal. Seharusnya pemerintah daerah menempatkan program restorasi gambut sebagai agenda penting. Pemerintah daerah tidak mau mengalokasikan secara khusus anggaran kegiatan restorasi gambut. Mereka masih berharap pada dana pemerintah pusat, baik dari Kementerian Lingkungan Hidup dan Kehutanan, maupun Badan Restorasi Gambut.

Hal ini telah sejalan dengan termuan penelitian yang dilakukan oleh Murat \& Schneider (2017), bahwa adanya kendala teknis birokrasi yang menyebabkan kegiatan restorasi gambut di daerah tidak dapat berjalan dengan lancar. "The Respondent from Disaster Management Office in Riau Province complains that the Peatland Restoration Agency is ineffective on the performance since they do nothing in the field. However, the respondent from the Peatland Restoration Agency explains that due to lack of resources and as a new institution, they were actively working in 2017, but hibernated in 2016. The Peatland Restoration Agency is a national institution that does not have a structural branch in the local area. He elaborates that this agency creates an ad-hoc team locally consisting of several local government offices to help implementation of project strategies" Dalam hal penegakan hukum, baik implementasi undang-undang maupun peraturan yang berlaku, korporasi perkebunan kelapa sawit dan HTI merasa sudah patuh dan mengikuti peraturan dan perundangan tersebut. Pemerintah 
daerah juga umumnya memiliki persepsi positif pada korporasi, terutama korporasi besar yang tergabung dalam asosiasi resmi dan sudah melakukan sertifikasi, seperti RSPO (Roundtable Sustainable Palm Oil) dan ISPO (Indonesian Sustainable Palm Oil). Mereka berpendapat bahwa tidak mungkin korporasi melakukan pembakaran lahan dengan sengaja. Dalam penelitian ini ditemukan belum adanya kesadaran kolektif bahwa kesalahan masa lalu dalam hal pengeringan lahan gambut merupakan sumber malapetaka bencana asap di Indonesia.

Begitu juga dengan penegakan hukum terhadap pelaku kebakaran. Polisi menyadari ini bahwa pada umumnya pelaku yang tertangkap adalah orang-orang suruhan yang secara ekonomi lemah. Bahkan, pihak kepolisian meminta kepada akademisi untuk meneliti guna mengetahui motif pelaku pembakar lahan oleh petani. Kenyataannya, kebakaran tetap saja terus berlangsung, meski sudah banyak pelaku yang tertangkap.

Respon korporasi terhadap kejadian bencana asap adalah membantu pemerintah, dengan cara bergabung di satuan tugas darurat bencana asap, menyediakan helikopter untuk patroli dan waterbombing. Korporasi juga membuat program-program CSR untuk desa-desa yang langsung berbatasan dengan konsesi mereka. Dapat dikatakan bahwa kegiatan pembinaan masyarakat tersebut adalah bentuk penyelamatan konsesi milik korporasi untuk menghindari kerugian yang lebih besar akibat kebakaran lahan gambut. Hal ini sejalan dengan temuan Alexander \& Blum (2016), dimana kepentingan ekonomi sangat dominan dalam persoalan lingkungan. Kepentingan ekonomi dapat mempengaruhi kepentingan politik dan juga hukum.

Dari diskursus agama juga dapat dilihat bahwa komunikasi agama yang dilakukan melalui dakwah pada sholat IedAdha, fatwa MUI, yang pesannya tentang larangan membakar hutan dan lahan, tidak juga membuat jera pelaku pembakar lahan. Persoalannya adalah bahwa ulama-ulama tersebut tidak mengetahui akar masalah kenapa bencana asap ini selalu berulang setiap tahunnya. Mereka setuju untuk berdakwah mencegah kerusakan di muka bumi oleh ulah tangan manusia, namun sebenarnya mereka tidak paham dengan akar masalah kejahatan lingkungan penyebab kebakaran lahan gambut.

Gejala-gejala tersebut diatas yang dilihat dari bagaimana masing-masing pihak merespon persoalan kebakaran lahan gambut menunjukkan adanya autopoietic system di dalam sistem sosial masyarakat (Luhmann, 1989). Masingmasing pihak selalu terbuka, mendengar setiap pandangan-pandangan ataupun masukan dari pihak lain terhadap solusi permanen bencana asap. Mereka mencoba memahami persoalanpersoalan yang dihadapi oleh pihak lain. Akan tetapi, ketika mereka akan bertindak, mereka kembali mengacu pada kepentingan masingmasing. Parapihak akan berpikir apakah tindakan tersebut memberikan keuntungan atau kerugian, sehingga perlu dilakukan atau tidak. Jika mereka melakukannya harus sesuai dengan fungsi mereka di dalam sistem sosial.

\section{Simpulan}

Bencana asap, akibatkebakaran lahan gambut telah disadari oleh para pihak sebagai kesalahan manusia dalam mengelola eksosistemnya. Bencana asap seharusnya dapat diatasi oleh manusiajikamemahamiakarpersoalan.Parapihak perlu mengkomunikasikan ide penyelesaiannya sehingga diperoleh solusi permanen. Dari interaksi tersebut dapat dilihat berbagai diskursus tentang solusi permanen yang dapat dilakukan untuk menyelesaikan persoalan bencana asap yang masih terjadi hingga tahun 2018 .

Diskursus yang muncul dalam mencari solusi permanen oleh para pihak, baik di Kalimantan barat maupun Riau meliputi ketersediaan air, masyarakat peduli api, tanggung jawab korporasi dalam pembinaan 
masyarakat, pendekatan agama, dan upaya restorasi lahan gambut. Beragamnya diskursus, dan bagaimana masing-masing pihak merespon setiap tawaran solusi yang ada, menunjukkan adanya gejala autopoiesis. Masing-masing pihak bersedia dan terbuka untuk mendengar, bahkan setuju dengan pandangan pihak lain, tetapi hanya akan melakukan implementasi solusi permanen yang ditawarkan, jika hal tersebut memberikan keuntungan. Oleh sebab itu, peneliti menyarankan kepada para pihak untuk tidak memaksakan ego kepentingannya masing-masing dalam penyelesaian kebakaran lahan gambut di Indonesia.

\section{Daftar Pustaka}

Alexander, D., \& Blum, V. (2016). Ecological economics: A Luhmannian analysis of integrated reporting. Ecological Economics, 129, 241-251. https://doi. org/10.1016/j.ecolecon.2016.06.020

Arifudin, Nasrul, B., \& Maswadi. (2013). Program of Community Empowerment Prevents Forest Fires in Indonesian Peat Land. Procedia Environmental Sciences, 17, 129-134. https://doi. org/10.1016/j.proenv.2013.02.020

Carmenta, R., Zabala, A., Daeli, W., \& Phelps, J. (2017). Perceptions across scales of governance and the Indonesian peatland fires. Global Environmental Change, 46(August), 50-59. https://doi. org/10.1016/j.gloenvcha.2017.08.001

Dohong, A., Aziz, A. A., \& Dargusch, P. (2017). A review of the drivers of tropical peatland degradation in SouthEast Asia. Land Use Policy. https://doi. org/10.1016/j.landusepol.2017.09.035

Huang, S. (2017). The Discourse Analysis of Haze Issue in China Critical Discourse Analysis about Constructions of People
Daily and Analysis of Audiences Interaction in Terms of Haze Issue Title: The Discourse Analysis of Haze Issue in China. Kittie, S., Schouten, G., \& Hein, L. (2018). Land Use Policy The institutional fi $t$ of peatland governance in Indonesia. Land Use Policy, (March), 0-1. https://doi. org/10.1016/j.landusepol.2018.03.031 Leydesdorff, L. (2014). Can inter-human communicationsbemodeledas “Autopoietic”? Constructivist Foundations, 9(2), 168-170.

Luhmann, N. (1982). The world society as a social system. International Journal of General Systems. https:// doi.org/10.1080/03081078208547442

Luhmann, N. (1989). Ecological Communication. The University of Chicago Press, Polity Press.

Luhmann, N. 1995. Sosial System. Translated by Jhon Bednarz,Jr. The University of Chicago Press. Maturana, H. R., and Varela, F. G. (1980). Autopoiesis and Cognition: The Realization of the Living, Reidel, Dordrecht. Murat,A.,\&Schneider,M.(2017). TheCaseofForest Fire Policy Design in Indonesia, (November).

Naruse, M., \& Iba, T. (2008). Ecosystem as an Autopoietic System. In Japan-North Amaerica Mathematical Sociologi Conference. Technology, 64(7):1442-1453

Ritzer. G. 2014. Teori Sosiologi Modern. Edisi Ketujuh. Prenada Media Grup. Jakarta. Safitri, M. A. (2016). Peatland Restoration in Indonesia Indonesian. Presentation at Japan Pavilion of COP 22, Marrakech November 11, 2016. Tata, H. L., Narendra, B. H., \& Ginoga, K. L. (2017). Drivers, Pressures, Impacts, Response Analysis Of Peatland Fire In Sumatra, Indonesia, (August), 14-17. Zadok. (2017). The Flght in the Haze. The University of Waikato. 